\title{
A Comparative Analysis of Brazil's Foreign Policy Drivers Towards the USA: Comment on Amorim Neto (2011)*
}

\author{
Fernando Mourón \\ PhD Candidate in International Relations, Universidade de São Paulo, Brazil \\ Francisco Urdinez \\ PhD Candidate in International Relations, Universidade de São Paulo, Brazil
}

\begin{abstract}
This paper looks at the main finding by Amorim Neto (2011), namely that Brazil's power explains why it distanced itself from the country that had once been its great ally in the first half of the last century. We propose an alternative explanation grounded on the realist literature in IR. Ultimately, we seek to determine whether the variable has behaved in the same way for other South American countries, searching for independent variables that could help us explain a visible pattern in the region: the increasing distancing from the United States (USA) at the United Nations General Assembly. We want to contribute to the debate initiated by Amorim Neto (2011) and Schenoni (2012) for future research in the recent field of quantitative analysis of Brazilian Foreign Policy. Using Panel Corrected Standard Error analysis in ten South American countries from 1970 to 2007 we empirically prove that the lower the power gap between a South American country and the U.S., the lower its alignment with the USA in the UN General Assembly voting.
\end{abstract}

Keywords: Brazilian foreign policy; South America; USA; UN general assembly; panel data econometrics.

\section{Introduction}

-1 ven with the unprecedented interest in Brazil, not much attention has yet been

given to the research area encompassing the quantitative analysis of the Brazilian Foreign Policy (PEB). Even though until recently the empirical research on the matter was very limited (OLIVEIRA, 2005, p. 27), the recent book by Amorim Neto (AN) De Dutra a

(*) $\quad$ http://dx.doi.org/10.1590/1981-38212014000100013

The replication dataset can be found in bpsr.org.br/files/arquivos/Banco_Dados_Mouron_Urdinez.html.

The authors would like to thank the three anonymous reviewers of the paper for their valuable suggestions. They also thank Amâncio Nunes de Oliveira and Andrés Malamud for their feedback, and Guy Whitten and Antonella Bandiera for their methodological suggestions. Everything written here is of the sole responsibility of the authors. This paper was presented in the ECPR 2013 Congress. This research was supported by Grant 2013/23251-9 and Grant 2014/03831-3, Fundação de Amparo à Pesquisa do Estado de São Paulo (FAPESP). 
Lula: A Condução e os Determinantes da Política Externa Brasileira (From Dutra to Lula: The Determinants of Brazilian Foreign Policy) (2011) has been a turning point.

Since its publication this work has been used as basis for other papers (RODRIGUEZ, 2012), reviewed (MALAMUD, 2012), quoted (MILANI, 2011; SPOSITO, 2014) and also criticized (SCHENONI, 2012; SENNES, 2011) ${ }^{1}$, so it deserves an in depth analysis. Before continuing, we should clarify that we will not attempt to carry out an in-depth and thorough Foreign Policy analysis and neither will we replicate AN's model for other countries. Rather, we want to initiate a debate with the aforementioned author and demonstrate the weak conceptual grounding of the main finding in his book regarding the realist variable. He argues that as Brazil came to be a more powerful State it could distance itself from the United States of America (USA) within the United Nations General Assembly (UNGA) voting and have a more independent conduct.

AN's book is based on the assumption that the degree of convergence with one of its main allies - namely the USA (HIRST, 2009; PINHEIRO, 2004) - within the United Nations General Assembly (UNGA) is a good indicator to understanding the determinants of the PEB. However, even when the use of this strategy has been justified by an extensive bibliography (BOOCKMANN and DREHER, 2011; DREHER et al, 2008; KIM and RUSSETT, 1996; POTRAFKE, 2009; RIESELBACH, 1960), all the countries of South America have followed a similar behavioral pattern in the UNGA for the 1970-2007 period and this needs to be explained (see Appendix A).

The objective of this paper is to look at the causes of this analogous behavior and show that it is not the country's power that explains its voting independence within the UNGA (as AN stated for Brazil), neither the declining power of the USA, as was argued in a response to AN's work, by Schenoni (2012). Rather, after a bibliographic review of the concept of power in International Relations we empirically demonstrate that what matters is the relation of power between two countries and the power gap between them.

On the other hand, with reference to the theory of complex interdependence (KEOHANE and NYE, 1987) that was also considered by AN, we test new indicators based on the existing literature (DREHER and STURM, 2012; OATLEY and YACKEE, 2004; THACKER, 1999; WOODS, 2003), to look for complementary variables that can explain the behavior of South American countries within UNGA.

Finally, using widely tested databases on democracy (GASTIL, 1991; MARSHALL and JAGGERS, 2002) and based on historiographical information, we test whether South American authoritarian regimes have tended to be closer to the USA than democratic ones.

Our paper is structured as follows: the next section presents the theoretical framework and the hypothesis of our work. Secondly, we proceed to some methodological clarifications concerning the models and their reading. Thirdly, we analyze the results. Finally, we arrive at the conclusions and implications of the work, highlighting its strengths and pinpointing a few caveats.

\section{Theoretical framework and hypothesis}

Using a Tobit model, AN's work attempts to explain the convergence between Brazil and the United States in UNGA according to nine explanatory variables, three structural and six domestic ones: (a) an indicator of national capabilities to measure power as understood by realism; (b) USA's participation in Brazil's annual exports; (c) a dummy variable to control for the end of the Cold

1 Amorim Neto (2011) was considered the Best Book in International Relations for 2012 by the Brazilian Association of Political Science (ABCP) and won the Award Vitor Nunes Leal. 
War; (d) the number of ministers belonging to leftist parties for each given year; (e) the president's ideology; (f) the ideological leaning of his cabinet; ( $g$ ) the legislative share of the president's party; (h) the legislative strength of left-to-the-center parties; (i) diplomatic inertia.

Among the structural variables the author dismisses variables (b) and (c) for lacking statistical significance. The domestic variables (e), (f), (g) and (h) also showed statistically insignificant results and therefore AN decided to omit them from his final model.

The conclusion he arrives at is that only variables (a) and (i) are significant at a $1 \%$ level. This can be read as: small variations in national capacities in Brazil had great impact on the convergence between Brazil and the United States (AMORIM NETO, 2011, p. 183) and strong diplomatic inertia found in statistical tests can be read as an acknowledgment of the key role played by Itamaraty in steering Brazilian external policy (AMORIM NETO, 2011, p. 159).

That is:

[...] the neorealist systemic factor was the most important since as the Brazilian economy grew and industrialized itself, population expanded, society urbanized, and military spending increased, and the size of the armed forces grew, the country was feeling able to, step by step, distance itself from the country who had been its great ally in the first half of the last century (AMORIM NETO, 2011, p.171).

For its part, variable (a) explains the inertial power of Itamaraty, and variable (d) the importance of ideology in the domestic arena, which allowed to assert that "in addition to affirming neorealist theory, this book also highlights the importance of bureaucracy and ideological identity of the actors who run the State in determining foreign policy "(AMORIM NETO, 2011, p.176).

From his finding we ask: how is it possible to explain the high degree of convergence in the UNGA voting between Brazil and other South American countries when it is impossible to consider in the existence of an agreed strategy? Nowadays there are different interpretations of the role played by Brazil in South America (VARAS, 2008, p. 02) which makes it difficult to define the role played by the country in the region (HAKIM, 2010, p. 49). In return, even if there is dissent in relation to Brazil's position in South America and especially when it comes to discuss "leadership" (MOURON, 2012, p. 12), there is a consensus within the academic community that only after the end of the Cold War Brazil for the first time carried out a policy of engagement with its South American neighbors (BETHELL, 2010, p. 417).

Therefore, by taking AN's thought-provoking results as a starting point as well as the debate initiated by Schenoni (2012), in the following sections we shall address three issues, namely: If a country has lost relative power over the years, then should it show an increasing convergence with the USA in UNGA voting? (See Appendix B). Also, does the American power itself explain the greater independence of a country in the UNGA voting? Furthermore, does the fact that Brazil has increased its power provide enough evidence for AN to affirm that it was the cause of the observed voting behavior?

As a secondary objective of this paper we test new variables that we believe might show some significance. Is the American participation in annual exports to Brazil the best available indicator to represent theories on complex interdependence? Sennes (2011) questions the choice of USA's participation in annual exports from Brazil as an independent variable that could reflect the interdependence between the two countries. According to him, this "... understates much more structural and critic matters to the country, such as the American involvement in FDI to Brazil [or the] importance of the country in the public and private 
financial flows ..." (SENNES 2011, p. 208). Finally, and following Spektor's (2009) writing on the Brazilian case, the following question arises: Did authoritarian regimes affect the alignment of South American countries with the USA?

Thus, to answer the above questions we formulated three hypothesis:

Hypothesis 1: The lower the Power Gap between a country and the USA, the lower its alignment with the latter in UNGA voting.

We will use the Weberian-inspired concept of power coined by Robert Dahl in his classic text The Concept of Power (1957), and later resumed by Richard Emerson (1962), Steven Lukes (1974) and developed in IR by David Baldwin $(1971,1979,1980)$, Jeffery Hart (1976) and later by Waltz $(1979,1993)$, which assumes that power among countries has a relational nature ${ }^{2}$. This work is different from the one-dimensional vision of power in AN (2011), who only observes the increase or decrease in power of Brazil as well as the concept used by Schenoni (2012) who considers that it is not the growing power of Brazil which accounts for its greater independence from USA, but the progressive weakening of American power.

This vision of power is therefore different from the one-dimensional view in AN (2011) and in Schenoni (2012) as it will take into account the power of both countries, reversing the coefficient symbol as it is expected a positive relationship between the alignment of USA and South American pair in the UNGA and the power gap of both. Thus, power is measured as the gap between USA's power and the power of the South American country in question. For example, Brazil is more powerful than Paraguay in 2006, it is therefore expected that the power differential between USA and Brazil is smaller than the difference between Paraguay and USA. Then, we refer to a true realistically-read relationship, while the power is conceived as a relationship of "spheres" whose gravitational forces are canceled. "A" has power over "B" to the extent that it achieves "B" do something that otherwise would not do (DAHL, 1957).

Figure 1. Graphical representation of the gap of power between two countries

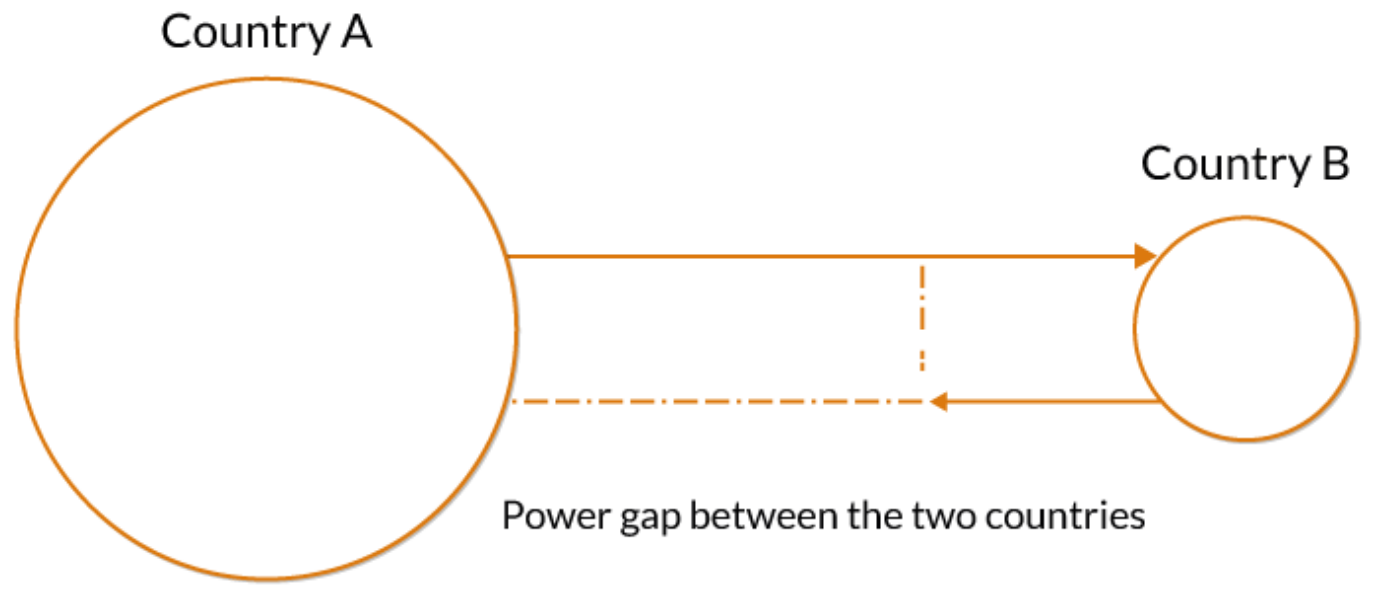

Source: Elaborated by the authors

$2 \quad$ "The intuitive idea of power is something like this: A has power over B to the extent that he can get B to do something that B would not do otherwise." (WALTZ, p. 202) "Power is here defined in terms of a relation between actors, and is expressed in simple symbolic notation. From this definition a statement of power comparability is developed, or the relative degree of power held by two or more persons." (WALTZ, p. 201) "Actors may be individuals, groups, roles, offices, governments, nation-states, or other human aggregates” (WALTZ, 1979, p. 203). 
It is rather surprising that the author has not calculated power as a relationship, as suggested here, even when he references Waltz (1979), who "emphasizes the 'relational properties' (mainly military power and economic) as major determinants of international state action" (AMORIM NETO, 2011, p. 19). The operationalization of this hypothesis is carried out by using a National Material Capabilities Index (CINC) composed of six indicators, which are (1) Total population, (2) Urban population, (3) Iron and steel production, (4) Energy consumption; (5) Military personnel, (6) Military expenditures.

Hypothesis 2a. The greater the flow of Foreign Direct Investment in a South American country;

Hypothesis $\mathbf{2 b}$. the greater the funding from the International Monetary Fund;

Hypothesis 2c. and the more funding from the World Bank, the greater the likelihood that the country is more aligned with the USA within the UNGA.

First we seek to measure if the flow of Foreign Direct Investment had any impact on the degree of alignment of South American countries with the US in the UNGA. Why this choice of variable? Since most of the FDI came from Advanced Industrialized Democracies we believe that voting in UNGA could have been influenced by a "carrot and stick" behavior on behalf of incoming investments. While there are studies that have shown that the frequency of military raids (EMMERT and TUMAN, 2004, p. 16) and the type of institutions in South American countries (BIGLAISER and STAATS, 2010, p. 16) had a significant relevance on FDI flows to the region, there are no known studies that have taken this variable as explanatory to the degree of convergence at the UN between US and South American countries.

In turn, Dreher and Sturm (2006) find that countries that borrowed from the World Bank and the International Monetary Fund voted in alignment with G7 countries, indicating that the source of funding partly determines the behavior of recipient countries in the international arena. Taking this article as reference one of the possible explanations for why much of the South American countries voted similarly in the UN General Assembly in relation to USA could be the great influence it had on the IMF and the WB.

We believe that financing in the region could have been conditioned by votes in the UNGA. A superb paper on the matter is Stone (2004), which uses data on 53 African countries from 1990 to 2000 to show that the IMF's loans-for-reform contracts were conditioned by voting in the UNGA' ${ }^{3}$. As he notes "Access to Fund financing varies widely, and recent studies have demonstrated a relationship between IMF lending and countrie's voting patterns in the United Nations (UN) General Assembly." (STONE, 2004, p. 578).

Moreover, since we are analyzing a subcontinent that comprises twelve independent countries and three overseas regions, it is remarkable that there are significant differences among them (DE SEBASTIAN, 1998, p. 15) and that the experiences of those in the second half of the twentieth century were varied (THORP, 1998, p. 213). However, if there is something in common in the financing process of South American countries after World War II is that financial flows came through institutions originating in the USA before other countries - especially West European ones - increased their participation over them and became internationalized (GRIFFITH JONES, 1984, p. 14). Therefore, it can be concluded that the rate by which South American countries were funded for years was largely marked by policies

3

See also Stone (2008). 
formulated from the US ${ }^{4}$.

Hypothesis 3. The probability that a South American country has a greater alignment in the UNGA with the USA increases during an authoritarian regime.

While South American military regimes from the period ranging the 30s and 80s were in fact very different, in the words of Alain Rouquie it can be argued that for much of the twentieth century a lasting military hegemony was predominant within the region in which an institutionalized military tutelage exerted great influence over the State (ROUQUIÉ, 1997, p. 294). Although all these regimes shared the goal of establishing a new order and a subordinate society, the political plan to achieve those goals depended, in each case, on countless variables (ACUÑA and SMULOVITZ, 1996, p. 125) among which should be mentioned the interference and influence of the USA.

One aspect common to all dictators who came to power in the late 60 s and 70 s is that they were part of a generation of officers trained during the Cold War on a counterinsurgency strategy (ROUQUIÉ, 1997, p. 300) and once in power participated within the framework of Operation Condor ${ }^{5}$. It is a fact that American presidents often supported dictators who allied with the USA (MAY and ZELIKOW, 2006).

Does this mean that the authoritarian regimes in the region were unilaterally aligned with the USA? Not necessarily. While the interference of the USA has been analyzed in depth in the cases of Chile (QURESHI, 2009), Argentina and Brazil (SPEKTOR, 2009), all these authors highlight that it is not accurate to assert that the South American authoritarian regimes corresponded fully to guidelines dictated from the United States. However, there is a strong historiographical evidence to affirm the financial and logistic assistance of the USA towards these authoritarian regimes (MCSHERRY, 1999, 2002, 2012). As a counterpart, we think that voting in UNGA could have been influenced by a "carrot and stick" behavior on behalf of military assistance.

\section{Empirics}

The sample used in this work consists of ten South American countries, which are studied within the period of 1970-2007 using a panel-type statistical model employing STATA. Even though AN studied the period between 1946 and 2007, data on FMI lending, WB lending, and Foreign Direct Investment is only available from the 70's onwards. It is important to also mention that this paper considers South America -and not Latin America- as Brazil's region of reference ${ }^{6}$. However, Table 5 extends the findings to Latin America and other regions. The countries in our sample are: Argentina, Bolivia, Brazil, Chile, Colombia, Ecuador, Paraguay, Peru, Venezuela and Uruguay.

The dependent variable is the same as the one used by AN, namely, the degree of

\footnotetext{
$4 \quad$ The fact that funding was scarce in the 50's had to do with the lack of importance the region had for the USA right after World War II (GRIFFITH JONES, 1984, p. 26). This low priority would become even more apparent over time (THORP, 1998, p. 138), with the great exception of the Cuban Revolution, until the 80s during the debt crisis process (KUCZYNSKI, 1988).

$5 \quad$ Operative established in 1975, which laid the foundation for future cooperation between South American military dictatorships in the exchange of information on anti dictatorships and communist activities in the whole region.

6 Bethell (2010) discusses why Brazil is not "part" of Latin America.
} 
convergence in the voting at the UN General Assembly with each of the countries analyzed. Information regarding such convergence is obtained from the database built by Erik Voeten and Adis Merdzanovic ${ }^{7}$, which has a record of votes from all member countries of the UN General Assembly between 1946 and 2008. We did not discriminate votes by subject area, but have considered all votes equally. ${ }^{8}$ The aggregated variable is an index of similarity rating from 0 to 1 . This index is equal to:

\section{Index of Similarity $=$ Total number of votes on which two States converge total number of joint votes}

Being computed as 1 = "yes" or "approval", and $0=$ "no" or "disapproval".

Statistical data used for the operationalization of the six independent variables was taken from four major databases, as summarized in Table 1.

CINC is a composite index of six indicators, which are (1) Total population; (2) Urban population; (3) Iron and steel production; (4) Energy consumption; (5) Military personnel; (6) Military spending. The available data comprises the 1816-2007 period, but because of the limited data for the other independent variables we chose to work with the 1970-2007 period (BREMER, SINGER and STUCKEY, 1972).

We measured both the AN's original variable and the variable that measures the power gap. We called the first one Unilateral Power, and the second, Power Gap. We built a power gap index following the framework described in Figure 1. That is, the value for each of the ten South American countries in the study was calculated as the absolute value of the difference between the power of the USA, minus the power of the South American country. This means that the expected relationship in regards to the dependent variable is positive: the weaker the South American country the higher the value of the difference.

This calculation is consistent with Dahl's conception of power and is a synthesis of the work of AN (for whom Brazil's power was only relevant) and Schenoni (2012) (who suggested that only the USA was relevant).

For the variables Foreign Direct Investment (FDI), IMF loans and World Bank loans we used World Bank Data indicators. The indicators used to operationalize each of these variables were (a) Private capital flows, total (\% of GDP), (b) Use of IMF credit (DOD, current US\$), (c) Net financial flows, International Bank for Reconstruction and Development (NFL, current US\$).

(a) Private capital flows consist of net foreign direct investment and portfolio investment. Foreign direct investment is net inflows of investment to acquire a lasting management interest in an enterprise operating in an economy other than that of the investor. It is the sum of equity capital, reinvestment of earnings, other long-term capital, and short-term capital as shown in the balance of payments. The FDI included here is total net, that is, net FDI in the reporting economy from foreign sources less net FDI by the reporting economy to the rest of the world. Portfolio investment excludes liabilities constituting foreign authorities' reserves and covers transactions in equity securities and debt securities (WORLD BANK, 2013A).

7 United Nations General Assembly $\quad$ Voting Data", http://hdl.handle.
net/1902.1/12379UNF:5:NpHV5DXWPNWMWOrLGTjQY== Erik Voeten [Distributor] V5 [Version].
8 Amorim Neto considered two separate models (2011, p.182). The first one did not discriminate votes by
subject while the second one did, taking into account votes on Security and Politics. Model 1 and 2 did not differ
significantly.


(b) The use of IMF credit denotes member's drawings on the IMF other than amounts drawn against the country's reserve tranche position. It includes purchases and drawings under Stand-By, Extended, Structural Adjustment, Enhanced Structural Adjustment, and Systemic Transformation Facility Arrangements as well as Trust Fund loans. SDR allocations are also included in this category. Data are in current USA dollars (WORLD BANK, 2013B).

(c) Net financial flows received by the borrower during the year are disbursements of loans and credits less repayments of principal. The International Bank for Reconstruction and Development is the founding and largest member of the World Bank Group. Data are in current USA dollars (WORLD BANK, 2013C).

The variable Authoritarian Regime was tested through three common indicators in the Political Science literature to avoid common problems of measurement (MUNCK and VERKUILEN, 2002). Firstly, we tested a dummy created by the authors based on historiographical information. The existence of an authoritarian government that suppressed the democratic division of powers and free elections on a certain year was coded as 1 , otherwise as 0 . This variable follows the "minimalist" criteria used by Cheibub et al (2010). Secondly, we tested the existence of authoritarian regimes using Polity IV, which captures the regime authority spectrum on a 21-point scale ranging from -10 (hereditary monarchy) to +10 (consolidated democracy). The Polity scores can also be converted to regime categories: "autocracies" ( -10 to -6$)$, "anocracies" $(-5$ to +5$)$ and "democracies" $(+6$ to +10$)$. Finally we used the Political Rights Scale of Freedom House, which has rating of 1 through 7, with 1 representing the greatest degree of freedom and 7 the smallest degree of freedom.

Table 1. Sources of data for the Independent Variables

\begin{tabular}{ll}
\hline Independent Variable & Source \\
\hline Countries Unilateral Power (Amorim Neto, 2011) & CINC Index v4.0 \\
USA Power (Schenoni, 2012) & CINC Index v4.0 \\
Power Gap & CINC Index v4.0 \\
Foreign Direct investment (FDI) & World Bank Indicators \\
International Monetary Fund loans & World Bank Indicators \\
World Bank loans & World Bank Indicators \\
Military Dictatorship & Elaborated by the authors, \\
\end{tabular}

Source: Elaborated by the authors

The general model for this work can be summarized as:

Convergence in UNGA voting $_{\mathrm{i}, \mathrm{t}}=\beta_{0}+\beta_{1}$ Unilateral Power $_{\mathrm{i}, \mathrm{t}}+\beta_{2}$ USA Power $_{\mathrm{i}, \mathrm{t}}+$ $\beta_{3}$ Countries Power Gap ${ }_{\mathrm{i}, \mathrm{t}-1}+\beta_{4}$ FDI $_{\mathrm{i}, \mathrm{t}}+\beta_{5}$ International Monetary Fund loans $_{\mathrm{i}, \mathrm{t}}+$ $\beta_{6}$ World Bank loans $_{\mathrm{i}, \mathrm{t}}+\beta_{8}$ Authoritarian Regime $_{\mathrm{i}, \mathrm{t}}+\mathrm{e}_{\mathrm{i}, \mathrm{t}}$ 


\section{Model analysis}

We have first defined a model with only three explanatory variables and no corrections to the data. The country's unilateral power (as defined by AN), USA's power (as suggested by SCHENONI, 2012) and the one suggested by us, which we called the Power Gap. There is a theoretical reason to presume that our variable has a better fit that we justified with the classical Dahl paper. Appendix C shows the statistical results of our model.

The first two variants, Model 1 and Model 2, test the three realist variables to see which has a better fit. As can be seen, the Power Gap has a better explanatory power than AN's variable, but not to Schenoni's (2012). Then, under the same assumptions, we have included the other independent variables for a first full version of the model discussed above. These are Models 3 and 4. As can be seen, Power Gap is now the most significant power variable. The WB loans variable is significant, but its effect is almost zero. The variables on authoritarian regimes were all significant, but while the minimalist criteria and Polity IV behaved as expected, Freedom House Political Rights showed a slightly positive relation with the dependent variable. Even if they are useful so as to obtain a first impression of our data, models presented in Appendix C are misspecified in their assumptions, leading to overly optimistic conclusions.

It may be recalled that according to the Gauss-Markov assumptions, OLS estimators are the Best Linear unbiased estimators ("BLUE" for its acronym) if errors are independent of each other and identically distributed with constant variance. The independence is violated when errors in different units are correlated (contemporaneous correlation), or when errors within each unit correlates temporally (serial correlation), or both (see Appendix D). In turn, the equal distribution of errors is violated when the variance is not constant and thus has heteroskedasticity (see Appendix E). Another aspect that until recently was not considered in econometric analysis in International Relations was the control for unit roots, which can lead to spurious regressions. This control should be done before any other controls (see Appendix F).

How can we solve problems of non-stationarity, heterogeneity, heteroskedasticity, and autocorrelation? These problems can be solved using estimators of Feasible Generalized Least Squares (FGLS) or with Panel Corrected Standard Error (PCSE) (BECK and KATZ, 1995; BECK, 2001). We have no certainties that the Models presented by AN have controlled these issues. Our Models 5 and 6, presented in Table 2, use PCSE and corrects the problems of heterogeneity, heteroskedasticity and autocorrelation coefficients which give less optimistic, but more accurate estimators than Models 1 to $4^{9}$. Models 5 and 6 even display greater significance in the variable "Power Gap", and make AN's and Schenoni's variables non-significant. Any of the control variables show significance, except for the minimalist criteria of authoritarian regime.

9 On page 638 of the paper by Beck and Katz (1995), the authors note that Error Correction Models (ECM) automatically solve problems of heteroscedasticity and spatial correlation, but does not solve problems of temporal autocorrelation (AR1). To resolve the temporal correlation, before rolling the ECM, we use a lag in the Power Gap variable. This is justifiable since the effect of the explanatory variable on the dependent variable is not immediate. 
Table 2. Variations for PCSE estimation

\begin{tabular}{|c|c|c|c|c|c|c|}
\hline $\begin{array}{l}\text { Dependent variable: Percentage of } \\
\text { convergence with the U.S. in UNGA }\end{array}$ & Model 5.1 & Model 5.2 & Model 5.3 & Model 6.1 & Model 6.2 & Model 6.3 \\
\hline \multirow[t]{2}{*}{$\begin{array}{l}\text { Unilateral Power } \\
\text { (Amorim Neto, 2011) }\end{array}$} & 17.57 & 16.54 & 16.42 & - & - & - \\
\hline & $(0.21)$ & $(0.24)$ & $(0.25)$ & - & - & - \\
\hline \multirow[t]{2}{*}{ USA Power (Schenoni, 2012) } & - & - & - & 0.97 & 1.15 & 1.10 \\
\hline & - & - & - & $(0.23)$ & $(0.16)$ & (0.19) \\
\hline \multirow[t]{2}{*}{ Power Gap } & $3.12^{* * *}$ & $2.85^{* * *}$ & $2.77^{* * *}$ & $3.03^{* * *}$ & $2.79 * * *$ & $2.73^{* * *}$ \\
\hline & $(0.00)$ & $(0.00)$ & $(0.00)$ & $(0.00)$ & $(0.00)$ & $(0.00)$ \\
\hline \multirow[t]{2}{*}{ FDI } & 0.00 & 0.00 & 0.00 & 0.00 & 0.00 & 0.00 \\
\hline & $(0.30)$ & $(0.25)$ & $(0.27)$ & $(0.25)$ & $(0.21)$ & $(0.23)$ \\
\hline \multirow[t]{2}{*}{ IMF Loans } & -0.00 & -0.00 & -0.00 & -0.00 & -0.00 & -0.00 \\
\hline & $(0.78)$ & $(0.79)$ & $(0.81)$ & $(0.63)$ & $(0.63)$ & $(0.66)$ \\
\hline \multirow[t]{2}{*}{ WB Loans } & 0.00 & 0.00 & 0.00 & 0.00 & 0.00 & 0.00 \\
\hline & $(0.51)$ & $(0.48)$ & $(0.46)$ & $(0.54)$ & $(0.53)$ & $(0.50)$ \\
\hline \multirow[t]{2}{*}{$\begin{array}{l}\text { Authoritarian Regime } \\
\text { (minimalist criteria) }\end{array}$} & $0.05^{*}$ & - & - & $0.05^{*}$ & - & - \\
\hline & $(0.02)$ & - & - & $(0.03)$ & - & - \\
\hline \multirow[t]{2}{*}{ Authoritarian Regime (Polity IV) } & - & -0.00 & - & - & -0.00 & - \\
\hline & - & $(0.16)$ & - & - & $(0.14)$ & - \\
\hline \multirow[t]{2}{*}{$\begin{array}{l}\text { Authoritarian Regime } \\
\text { (Freedom House) }\end{array}$} & - & - & -0.00 & - & - & -0.00 \\
\hline & - & - & $(0.72)$ & - & - & $(0.73)$ \\
\hline \multirow[t]{2}{*}{ Constant } & $-0.02^{* *}$ & $-0.02 * * *$ & $-0.02^{* * *}$ & $-0.02^{* *}$ & $-0.02^{* *}$ & $-0.02^{* * *}$ \\
\hline & $(0.00)$ & $(0.00)$ & $(0.00)$ & $(0.00)$ & $(0.00)$ & $(0.00)$ \\
\hline Observations & 328 & 328 & 322 & 328 & 328 & 322 \\
\hline
\end{tabular}

${ }^{*} \mathrm{p}<0.05,{ }^{* *} \mathrm{p}<0.01,{ }^{* * *} \mathrm{p}<0.001$

Models 5 and 6 controlled for the temporal autocorrelation (AR1) and the existence of unit roots in the variables. Their different versions correspond to the use of different criteria to measure Authoritarian Regimes. After controlling for non-stationarity, heterogeneity, heteroscedasticity and autocorrelation (AR1), Power Gap variable remains significant, while this is not the case for Unilateral Power and USA Power. The interpretation of this coefficient is as follows: a $1 \%$ increase in the power gap between the USA and a South American country has a positive effect on the convergence in UNGA of between $2.73 \%$ and $3.12 \%$, depending of the specification of the model. Meanwhile, a country under an authoritarian regime holds a $5 \%$ increase in UNGA convergence with the U.S., when measured with the minimalist criteria. With respect to liberal variables "Foreign Direct Investment", "International Monetary Fund lending" and "World Bank lending", we can state they show no statistical relationship with the dependent variable and can therefore be added to the variables already tested by AN that did not have statistical significance ${ }^{1}$.

Since we have a strong theoretical reason to propose the use of Power Gap as the 
best proxy for power, as understood in Realist terms, we believe that testing it in different geographical regions would give robustness to our finding. Table 3 shows the behavior of the three power variables in different samples of countries, corresponding to Latin America ${ }^{1}$, Africa $^{2}$, East Asia ${ }^{3}$ and Europe ${ }^{4}$.

Table 3. Checking the robustness of "Power Gap" in other samples

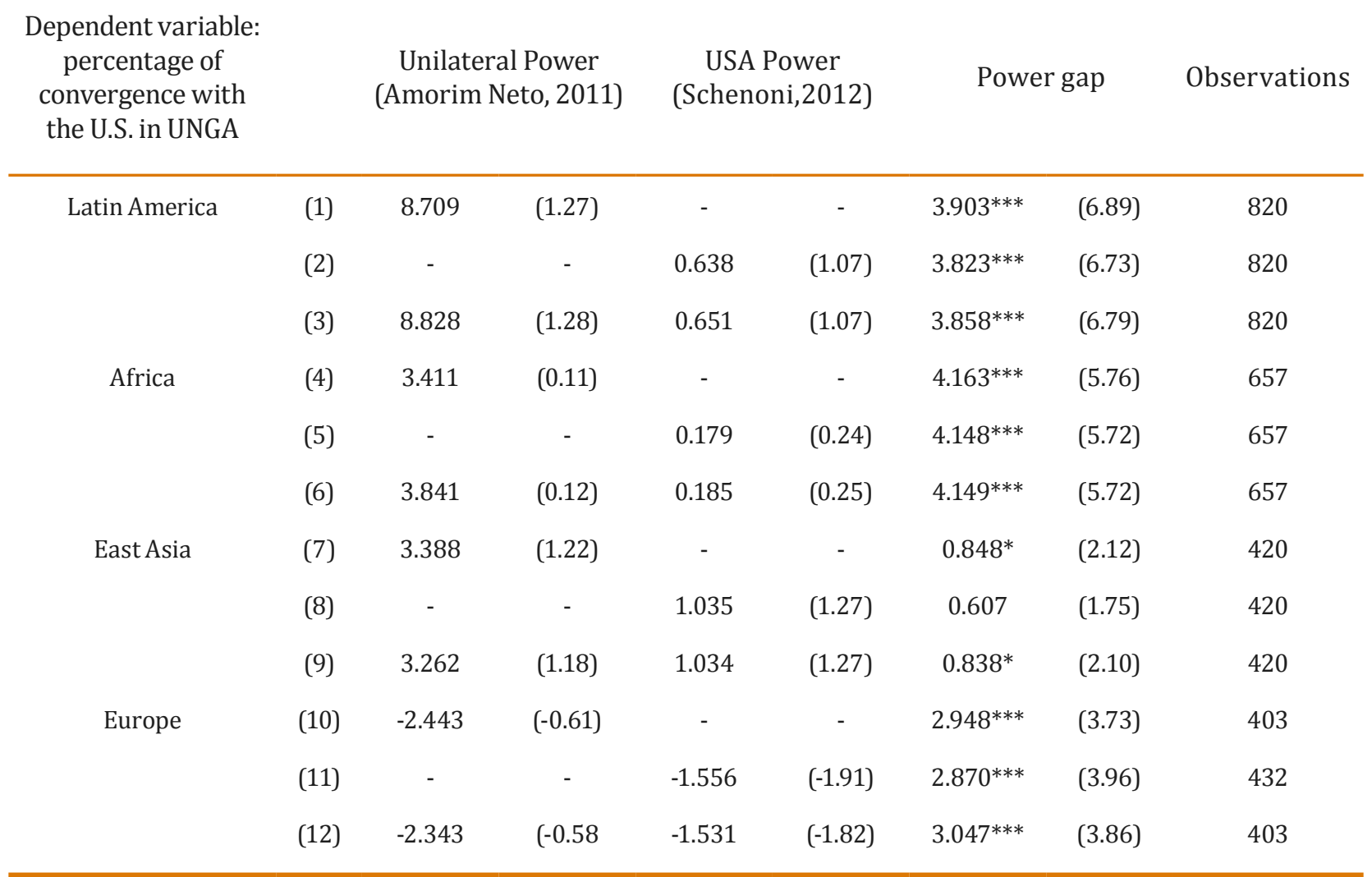

${ }^{*} \mathrm{p}<0.05,{ }^{* *} \mathrm{p}<0.01,{ }^{* * *} \mathrm{p}<0.001$

\section{Conclusions}

The results of the study show that there is a similar behavior pattern among the ten tested South American countries in the AGNU for the period 1970-2007. In order to explain this behavior, and according to the statistical results obtained, we are able to provide responses to the questions raised in the paper.

1 We considered Argentina, Bolivia, Brazil, Chile, Colombia, Costa Rica, Cuba, Dominican Republic, Ecuador, El Salvador, Guatemala, Guyana, Haiti, Honduras, Mexico, Nicaragua, Panamá, Peru, Suriname, Trinidad and Tobago, Uruguay, and Venezuela.

2 We considered Burkina Faso, Cameroon, Chad, Cote d'Ivoire, Equatorial Guinea, Gambia, Ghana, Guinea, Kenya, Lesotho, Liberia, Libya, Mali, Mauritania, Morocco, Niger, Nigeria, Senegal, and Sierra Leona.

3 We considered Cambodia, China, India, Indonesia, Japan, Malaysia, Myanmar, Nepal, Philippines, Singapore, Sri Lanka, and Thailand.

4 We considered Austria, Belgium, Finland, France, Greece, Ireland, Italy, Netherlands, Portugal, Spain, Sweden, and the United Kingdom. 
Firstly, the fact that a South American country weakened between 1970 and 2007 does not necessarily imply that that country got closer politically to the US, using the voting in the UNGA as a proxy. This is a counter intuitive conclusion with the results obtained by AN, who argued that the more powerful Brazil was, the more independent it would consequently become. On the other hand, the loss of power of the United States per se does not explain the distance in the voting pattern. Our paper finds that what matters is the power gap, measured in absolute terms, and the annual difference between the world power shares of the South American country and the USA. Therefore, power is conceived as a relationship and not as a resource. This variable is the most important systemic one and from which we may conclude that as the years passed and the power gap got smaller, South American countries had more room to have independent positions and leave the American orbit. We expanded this finding to a larger sample, which include other geographical regions, to give robustness to the results.

Secondly, any of the liberal systemic variables that have been tested showed statistical significance. We have therefore added three liberal variables that have shown no statistical significance (Foreign Direct Investment, International Monetary Fund credits, credits from the World Bank) to the one tested by AN (U.S. participation in annual exports from Brazil).

Thirdly, we did not find enough evidence to affirm that authoritarian regimes have shown a relatively greater alignment with the U.S. in the UNGA than democratic governments, even when there is strong historiographical evidence that can back this hypothesis.

We have contributed to a research line that has, for the first time, explained PEB through quantitative methods. In a time when research in IR in Brazil is booming we expect to see more debates like this. Further research in PEB should focus on the replicability of empirical work, and on the improvement of quantitative techniques.

Translated by Paulo Scarpa

Submitted in August 2013

Accepted in June 2014

\section{References}

ACUÑA, Carlos and SMULOVITZ, Catalina (1996), Ajustando las Fuerzas Armadas a la democracia. Las FF. AA. como actor político en la experiencia del Cono Sur. Ágora, № 05, pp. 97-133.

AMORIM NETO, Octavio (2011), De Dutra a Lula: A condução e os determinantes da política externa brasileira. São Paulo, São Paulo: Elsevier Editora.

BALDWIN, David A. (1971), The power of positive sanctions. World Politics, Vol. 24, № 01, pp. 19-38.

BALDWIN, David A. (1979), Power analysis and world politics: New trends versus old tendencies. World Politics, Vol. 31, № 02, pp. 161-194.

BALDWIN, David A. (1980), Interdependence and power: a conceptual analysis. International Organization. Vol. 34, № 04, pp. 471-506.

BECK, Nathaniel and KATZ, Jonathan (1995), What to do (and not to do) with Times-Series Cross-Sectional Data. The American Political Science Review. Vol. 89, Issue 03, pp. 634- 
647. From JSTOR. From http://www.bpsr.org.br/index.php/bpsr/article/view/180/168 BECK, Nathaniel (2001) Times-Series-Cross-Section Data: What Have We Learned in the Last Few Years? Department of Political Science. University of California, San Diego. From http://politics.as.nyu.edu/docs/IO/4756/beck_tscs.pdf

BETHELL, Leslie (2010), Brazil and "Latin America”. Journal of Latin American Studies. Vol. 42, №3, pp.457-485.

BIGLAISER, Glen and STAATS, Joseph L. (2010). Do political institutions affect foreign direct investment? A survey of US corporations in Latin America. Political Research Quarterly, 63(3), 508-522.

BOOCKMANN, Bernhard and DREHER, Axel (2011), Do human rights offenders oppose human rights resolutions in the United Nations? Public Choice. Vol. 146, № 03-04, pp.443-467.

BREMER, Stuart, SINGER, David and STUCKEY, John (1972), Capability Distribution, Uncertainty and Major Power War, 1820-1965. In: Bruce Russett (ed) Peace, War and Numbers, Beverly Hills: Sage, pp. 19-48.

CHEIBUB, José A., GANDHI, Jennifer, and VREELAND, James R. (2010), Democracy and dictatorship revisited. Public Choice. Vol. 143, № 01-02, pp. 67-101.

DAHL, Robert (1957), The Concept of Power. Behavioral Science. Vol. 02, № 03, pp. 201- 215. From http://65.99.230.10:81/collect/politics/index/assoc/HASHa8ee.dir/doc.pdf

DE SEBASTIÁN, Luis (1998), La crisis de América Latina y la deuda externa. Madrid: Alianza.

DREHER, Axel and STURM, Jan-Egbert (2006), Do IMF and World Bank Influence Voting in the UN General Assembly? KOF Swiss Economic Institute, ETH Zurich in its series KOF Working papers with number 06-137. From http://www.kof.ethz.ch/publications/ science/pdf/wp_137.pdf

DREHER, Axel, NUNNENKAMP, Peter, and THIELE, Rainer (2008), Does US aid buy UN general assembly votes? A disaggregated analysis. Public Choice. Vol. 136, № 01-02, pp.139-164.

DREHER, Axel and STURM, Jan-Egbert (2012), Do the IMF and the World Bank influence voting in the UN General Assembly? Public Choice. Vol. 151, № 01-02, pp. 363-397.

EMERSON, Richard M. (1962), Power-Dependence Relations. American Sociological Review. Vol. 27, № 01, pp. 31-41.

EMMERT, Craig and TUMAN, John (2004), The Political Economy of U.S. Foreign Direct Investment in Latin America. Latin American Research Review. Vol. 39. The University of Texas Press, Austin.

FRANKO, Patrice (2000), Toward a New Security Architecture in the Americas: The Strategic Implications of the FTAA. Center for Strategic \& Intl Studies: Washington DC.

GASTIL, Raymond. D. (1991), Freedom in the world: Political rights and civil liberties. Freedom House. GOYAL, Sanjeev and JOSHI, Sumit (2006), Bilateralism and Free Trade. International Economic Review. Vol. 47, № 03, pp. 749-778. Article Stable URL: http://www.jstor.org/ stable/3877469.

GREENE, William (2000), Econometric Analysis. Upper Saddle River, NJ: Pretience Hal.

GRIFFITH-JONES, Stephany (1984), International finance and Latin America. UK: St Martins Press.

GRUNWALD, Joseph (1993), Hemispheric Economic Integration? Some Reflections. Annals of the American Academy of Political and Social Science. Vol. 526, Free Trade in the Western Hemisphere, pp. 135-150. Article Stable URL: http://www.jstor.org/stable/1047473 
HAKIM, Peter (2010), O Brasil em ascensão: os desafios e as escolhas de uma potência global emergente. Revista Política Externa. Vol. 19, São Paulo.

HART, Jeffrey (1976), Three approaches to the measurement of power in international relations. International Organization. Vol. 30, № 02, pp. 289-305.

HIRST, Monica (2009), Brasil-Estados Unidos: Desencontros e afinidades. Rio de Janeiro: Editora FGV.

JAMES, Patrick and LUSZTIG, Michael (2003), The US Power Cycle, Expected Utility, and the Probable Future of the FTAA. International Political Science Review / Revue internationale de science politique. Vol. 24, № 01, Power Cycle Theory and Global Politics. Cycle de pouvoir et politique mondiale (Jan., 2003), pp. 83-96. Article Stable URL: http://www.jstor.org/stable/1601331

KEOHANE, Robert and NYE, Joseph (1987), Power and interpendence revisted. International Organization. Vol. 41, № 04, 1987, pp. 725-753.

KIM, Soo Yeon and RUSSETT, Bruce (1996), The new politics of voting alignments in the United Nations General Assembly. International Organization. Vol. 50, № 04, pp. 629-652.

KRISHNA, Pravin (1998), Regionalism and Multilateralism: A Political Economy Approach. The Quarterly Journal of Economics. Vol. 113, № 01, pp. 227-251. Article Stable URL: http://www.jstor.org/stable/2586990.

KUCZYNSKI GODARD, Pedro P.(1988). Latin American debt. Johns Hopkins University Press, Baltimore. LUKES, Steven (1974), Power: A radical view. Macmillan: London.

MALAMUD, Andres (2012), Power Matters: The Structural Sources of Brazilian Foreign Policy. Brazilian Political Science Review. Vol. 6, № 02, pp. 119-124. Article Stable URL: http:// www.bpsr.org.br/index.php/bpsr/issue/view/17

MARSHALL,Don(1998),NAFTA/FTAAand theNewArticulationsintheAmericas: Seizing Structural Opportunities. Third World Quarterly. Vol. 19, № 04, Rethinking Geographies: North-South Development, pp. 673-700. Article Stable URL: http://www.jstor.org/stable/3993250.

MARSHALL, Monty G. and JAGGERS, Keith (2002), Polity IV project: Political regime characteristics and transitions, 1800-2002: Dataset Users. Manual. Maryland: University of Maryland.

MAY, Ernest and ZELIKOW, Philip (2006), Dealing with Dictators. Dilemmas of U.S. Diplomacy and Intelligence Analysis, 1945-1990, MIT Press, U.S.

MCSHERRY, J. Patrice (1999), Operation Condor: clandestine inter-American system. Social Justice - San Francisco. Vol. 26, № 04, pp. 144-174.

MCSHERRY, J. Patrice (2002), Tracking the origins of a state terror network: Operation Condor. Latin American Perspectives. Vol. 29, № 01, pp. 38-60.

MCSHERRY, J. Patrice (2012), Predatory states: Operation Condor and covert war in Latin America. Rowman \& Littlefield Publishers, Lanham.

MILANI, Carlos (2011), Crise Política e Relações Internacionais: Uma Análise Escalar da Política Externa Brasileira. Paper presented at the VI Conferência Nacional de Política Externa e Política Internacional, Brasília.

MOURON, Fernando (2012), El rol de Brasil en Sudamérica. El concepto de liderazgo y su debate teórico. Paper presented at the VI Congreso de Relaciones Internacionales de la Universidad de La Plata, Argentina. 
MUNCK, Geraldo L. and VERKUILEN, Jay (2002), Conceptualizing and measuring democracy: Evaluating alternative indices. Comparative political studies. Vol. 35, № 01, pp. 5-34.

OATLEY, Thomas and JASON Yackee (2000), Political Determinants of IMF Balance of Payments Lending: The Curse of Carabosse? Working paper. University of North Carolina at Chapel Hill.

OATLEY, Thomas and YACKEE, Jason (2004), American interests and IMF lending. International Politics. Vol. 41, № 03, pp. 415-429.

OLIVEIRA, Henrique Aletimani de (2005), Política Externa Brasileira. São Paulo, SP: Saraiva.

PINHEIRO, Leticia (2004), Política Externa Brasileira. Rio de Janeiro: Jorge Zahar Ed.

POTRAFKE, Niklas (2009), Does government ideology influence political alignment with the US? An empirical analysis of voting in the UN General Assembly. The Review of International Organizations. Vol. 04, № 03, pp.245-268.

QURESHI, Lubna (2009), Nixon, Kissinger and Allende: U.S. Involvement in the 1973 Coup. In: Chile Lexington Books, Lanham.

RIESELBACH, Leroy. N. (1960), Quantitative techniques for studying voting behavior in the UN General Assembly. International Organization. Vol. 14, № 02, pp. 291-306.

RODRIGUEZ, Julio Cesar Cossio (2012), Chacal ou Cordeiro? O Brasilfrenteaos desafios e oportunidades do sistema internacional. Revista Brasileira de Política Internacional. Vol. 55, № 02, pp. 70-89.

ROUQUIÉ, Alain (1997), Los militares en la política latinoamericana desde 1930. In: Bethell, L. Historia de America Latina. Vol. 12. Barcelona: Crítica.

SCHENONI, Luis (2012), Los determinantes externos de la política externa brasilera en el contexto de América Latina. IV Congreso Uruguayo de Ciencia Política, Montevideo.

SENNES, Ricardo (2011), Reseña del libro De Dutra a Lula: A condução e os determinantes da política externa brasileira, de Octavio Amorim Neto. Política Externa. Vol. 20, № 03, Brasil.

SORJ, Bernardo and FAUSTO, Sergio (2011), O papel do Brasil na América do Sul: estratégias e percepções mútuas. In: Brasil e América do Sul: Olhares cruzados. Rio de Janeiro: Plataforma Democrática.

SPEKTOR, Matias (2009), Kissinger e o Brasil. Rio de Janeiro: Zahar.

SPEKTOR, Matias (2010), Ideias de ativismo regional: a transformação das leituras brasileiras da região. Revista Brasileira de Política Internacional. № 53, Brasília.

SPOSITO, Italo B. (2014), Foreign Policy Change in Brazil: Comparing Castelo Branco (1964-1967) and Fernando Collor (1990-1992). Brazilian Political Science Review. Vol. 07, № 03, pp. 118 -144.

STONE, Randall W. (2004), The Political Economy of IMF Lending in Africa. The American Political Science Review. Vol. 98, № 04 (Nov.), pp. 577-591.

STONE, Randall W. (2008), The Scope of IMF Conditionality. International Organization. Vol. 62, № 04 (Fall, 2008), pp. 589-620.

THACKER, Strom C. (1999), The High Politics of IMF Lending. World Politics. Vol. 52, № 01 (October), pp. 38-75.

THORP, Rosemary (1998), Progreso, pobreza y exclusión: una historia económica de América Latina en el siglo XX. Washington: BID.

VARAS, Augusto (2008), Brazil in South America: from indifference to hegemony. FRIDE. Tomado de http://www.fride.org/publicacion/415/brasil-en-sudamerica:-de-la-indiferencia-a-la-hegemonia.

WALTZ, Kenneth (1979), Theory of International Politics. Reading, MA: Addison- Wesley Publishing Co. WALTZ, Kenneth (1990), Realist thought and neorealist theory. Journal of International 
Affairs. Vol. 44, № 01, pp. 21-37.

WALTZ, Kenneth (1993), The emerging structure of international politics. International Security. Vol. 18, № 02, pp. 44-79.

WOODS, Ngaire (2003), The United States and the international financial institutions: Power and influence within the World Bank and the IMF. Foot, McFarlane and Mastanduno (Eds.), US Hegemony and International Organizations. Oxford, pp. 92-114.

WORLD BANK (2013a), Indicators: Private Capital Flows (\% of GDP). From http://datos. bancomundial.org/indicador/BN.KLT.PRVT.GD.ZS January 10, 2013.

WORLD BANK (2013b), Indicators: Use of IMF credit (DOD, current U.S. \$ prices). From http:// datos.bancomundial.org/indicador/DT.DOD.DIMF.CD January 10, 2013.

WORLD BANK (2013c), Indicators: Net financial flows, IBRD (NFL, current U.S. \$ prices). From http://datos.bancomundial.org/indicador/DT.NFL.MIBR.CD January 10, 2013.

\section{Apendix A}

Graphic 1. Behavioural pattern in the UNGA for selected South American countries 1970-2004

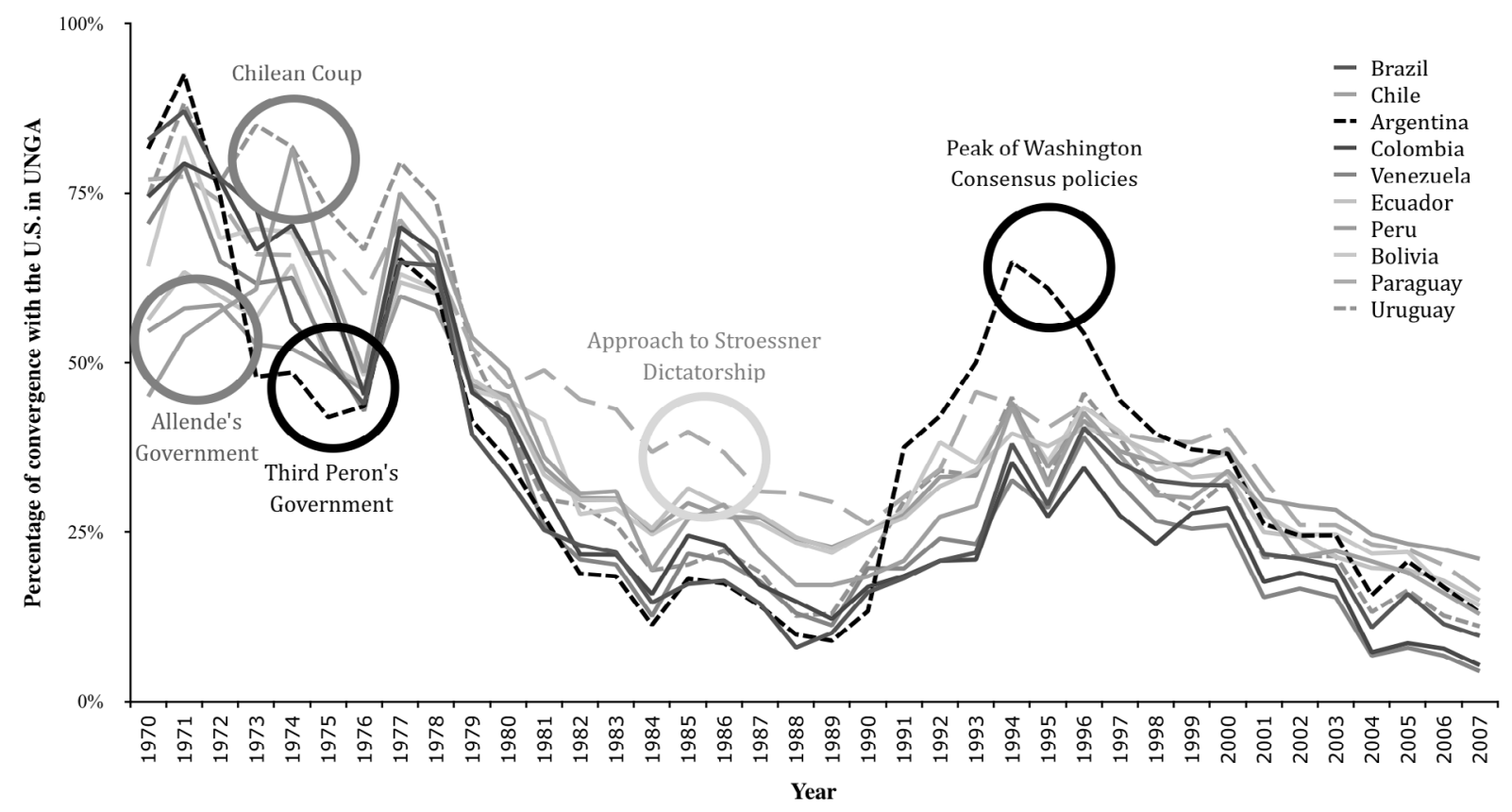




\section{Apendix B}

Looking at the percentage of convergence with the U.S. in the UNGA among South American countries it is perceptible that they all show a suspiciously similar pattern.

Graphic 2. Suspiciously similar pattern of convergence with the U.S. in the UNGA Amorim Neto concludes that:

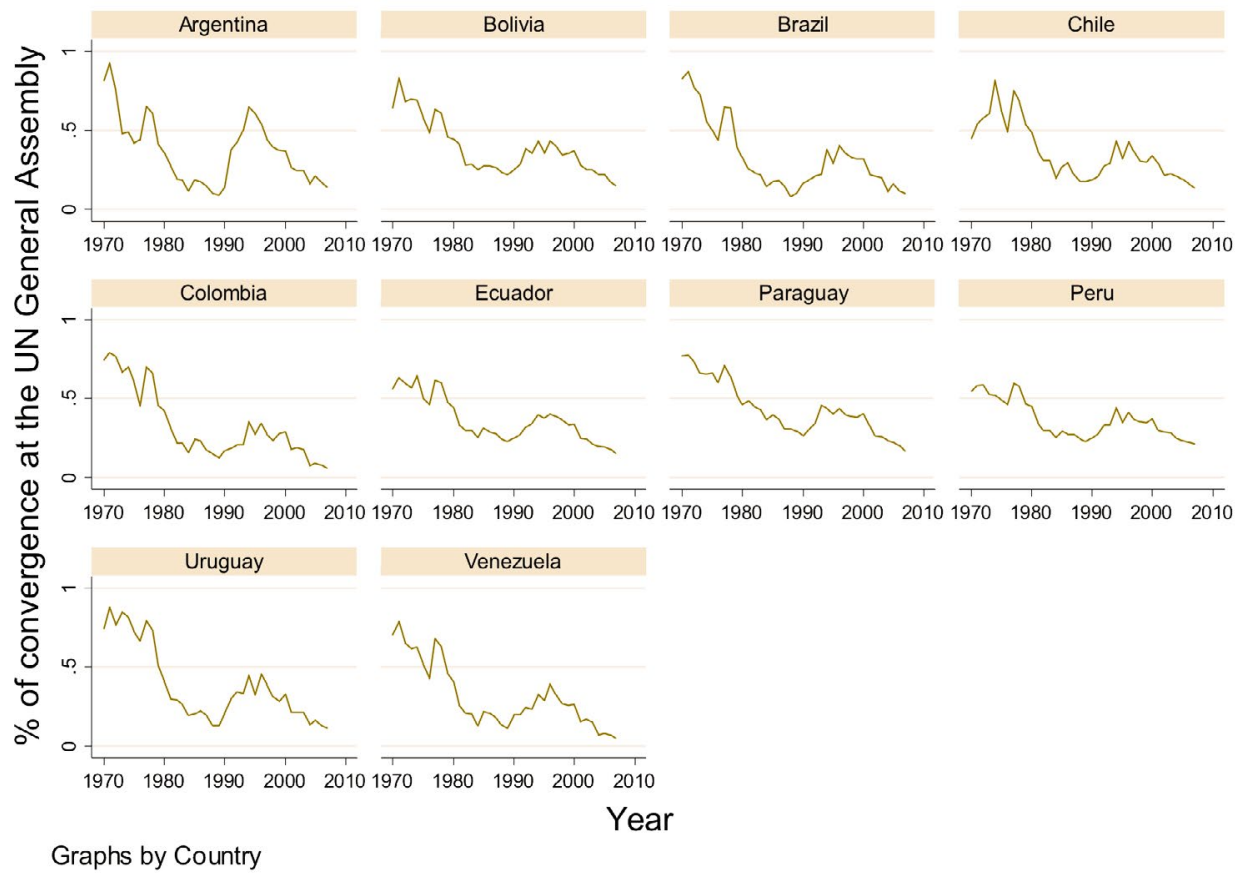

from the second half of the twentieth century, as the Brazilian economy grew and industrialized, its population expanded, its society urbanized, military spending increased as well as the size of the armed forces, the country felt it was able to, step by step, distance itself from the one who had been its great ally during the first half of the last century (AMORIM NETO, 2011, p. 171).

If we look at the figure above, does this mean that all these countries have strengthened between 1970 and 2010? If one looks at the image below, which shows the evolution of the extent of power of each country (measured with the same indicator used by the author for Brazil), we see that some countries such as Argentina, Uruguay and Venezuela not only did not increase their power, but it was actually weakened. 
Graphic 3. Dissimilar patterns in the evolution of national capacities
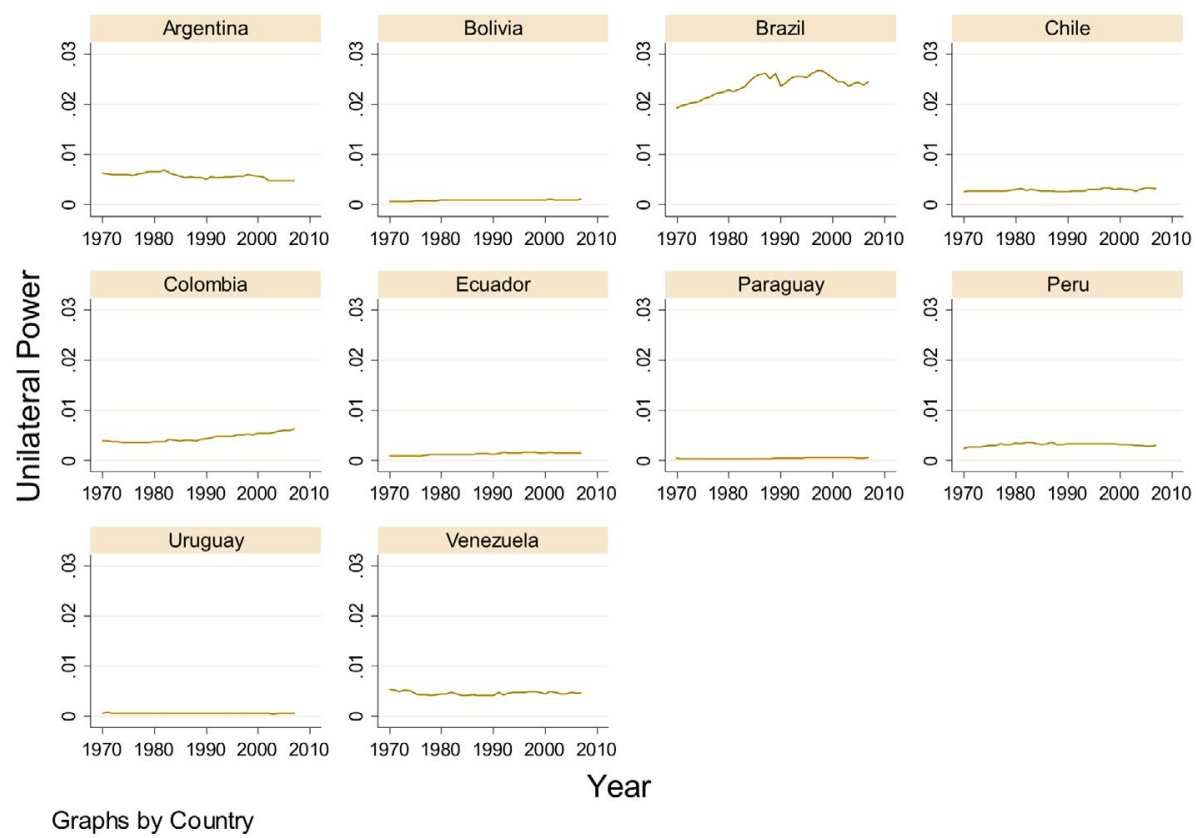

For that very reason and based on Robert Dahl's concept of power (1957), we suggest a measure of the variable in which all countries show a similar pattern in relation to the U.S. As mentioned in the body of the work we name this variable "Power Gap", which has been calculated as the absolute value of the difference between the power of country $i$ and the power of the U.S., for each year.

\section{Graphic 4. Power gap pattern}
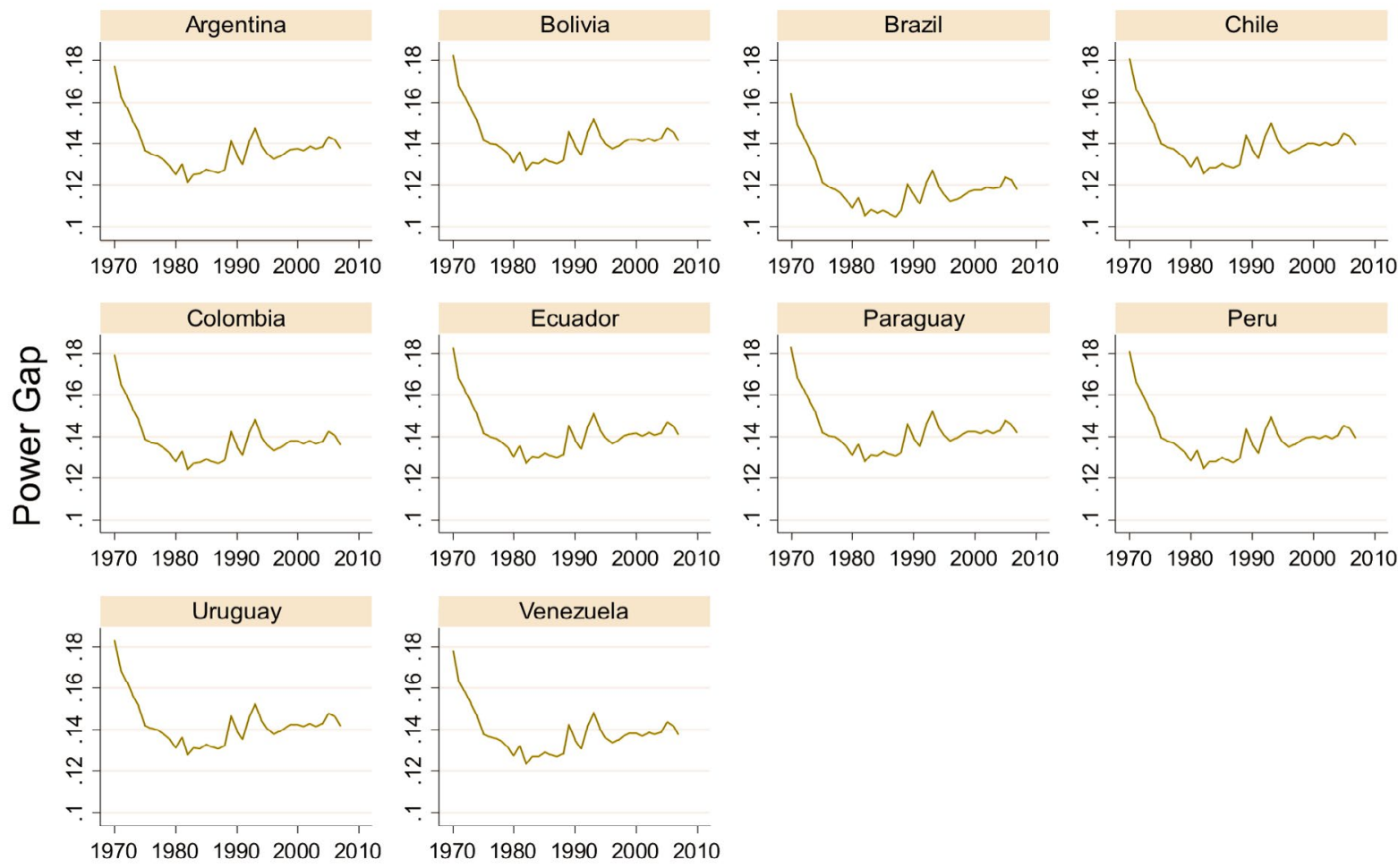

Graphs by Country

Year 


\section{Appendix C}

Table 4. Regression results, models 1 - 4

\begin{tabular}{|c|c|c|c|c|c|c|c|c|}
\hline $\begin{array}{l}\text { Dependent variable: } \\
\text { Percentage of convergence } \\
\text { with the U.S. in UNGA }\end{array}$ & Model 1 & Model 2 & $\begin{array}{l}\text { Model } \\
3.1\end{array}$ & $\begin{array}{c}\text { Model } \\
3.2\end{array}$ & $\begin{array}{l}\text { Model } \\
3.3\end{array}$ & $\begin{array}{c}\text { Model } \\
4.1\end{array}$ & $\begin{array}{c}\text { Model } \\
4.2\end{array}$ & $\begin{array}{c}\text { Model } \\
4.3\end{array}$ \\
\hline \multirow[t]{2}{*}{$\begin{array}{l}\text { Unilateral power } \\
\text { (Amorim Neto, 2011) }\end{array}$} & $5.92^{* *}$ & - & $4.91^{*}$ & $5.07^{*}$ & 0.59 & - & - & - \\
\hline & $(0.01)$ & - & $(0.02)$ & $(0.02)$ & $(0.83)$ & - & - & - \\
\hline \multirow[t]{2}{*}{ American power (Schenoni, 2012) } & - & $6.18^{* *}$ & - & - & - & $4.93^{*}$ & $5.08^{*}$ & 0.61 \\
\hline & - & $(0.01)$ & - & - & - & $(0.03)$ & $(0.02)$ & $(0.83)$ \\
\hline \multirow[t]{2}{*}{ Power gap } & $9.17^{* * *}$ & $3.21^{* * *}$ & $8.11^{* * *}$ & $7.89^{* * *}$ & 2.95 & $3.24^{* * *}$ & $2.86^{* * *}$ & $2.36^{* * *}$ \\
\hline & $(0.00)$ & $(0.00)$ & $(0.00)$ & $(0.00)$ & $(0.27)$ & $(0.00)$ & $(0.00)$ & $(0.00)$ \\
\hline \multirow[t]{2}{*}{ FDI } & - & - & 0.00 & 0.00 & 0.00 & 0.00 & 0.00 & 0.00 \\
\hline & - & - & $(0.83)$ & $(0.68)$ & $(0.32)$ & $(0.84)$ & $(0.69)$ & $(0.32)$ \\
\hline \multirow[t]{2}{*}{ IMF loans } & - & - & -0.00 & -0.00 & -0.00 & -0.00 & -0.00 & -0.00 \\
\hline & - & - & $(0.12)$ & $(0.08)$ & $(0.08)$ & $(0.12)$ & $(0.08)$ & $(0.08)$ \\
\hline \multirow[t]{2}{*}{ WB loans } & - & - & $-0.00^{* * *}$ & $-0.00^{* * *}$ & $-0.00 * * *$ & $-0.00^{* * *}$ & $-0.00^{* * *}$ & $-0.00^{* * *}$ \\
\hline & - & - & $(0.00)$ & $(0.00)$ & $(0.00)$ & $(0.00)$ & $(0.00)$ & $(0.00)$ \\
\hline \multirow[t]{2}{*}{$\begin{array}{l}\text { Authoritarian regime } \\
\text { (minimalist criteria) }\end{array}$} & - & - & $0.17^{* * *}$ & - & - & $0.17^{* * *}$ & - & - \\
\hline & - & - & $(0.00)$ & - & - & $(0.00)$ & - & - \\
\hline \multirow[t]{2}{*}{ Authoritarian regime (Polity IV) } & - & - & - & $-0.01^{* * *}$ & - & - & $-0.01^{* * *}$ & - \\
\hline & - & - & - & $(0.00)$ & - & - & $(0.00)$ & - \\
\hline \multirow[t]{2}{*}{$\begin{array}{l}\text { Authoritarian regime } \\
\text { (Freedom House) }\end{array}$} & - & - & - & - & $0.04^{* * *}$ & - & - & $0.04^{* * *}$ \\
\hline & - & - & - & - & $(0.00)$ & - & - & $(0.00)$ \\
\hline \multirow[t]{2}{*}{ Constant } & $-0.93^{* *}$ & $-0.96^{* *}$ & $-0.82^{* *}$ & $-0.69^{*}$ & -0.17 & $-0.83^{* *}$ & $-0.70^{*}$ & -0.17 \\
\hline & $(0.00)$ & $(0.00)$ & $(0.01)$ & $(0.02)$ & $(0.65)$ & $(0.01)$ & $(0.02)$ & $(0.65)$ \\
\hline Observations & 380 & 380 & 332 & 332 & 326 & 332 & 332 & 326 \\
\hline
\end{tabular}

${ }^{*} \mathrm{p}<0.05,{ }^{* *} \mathrm{p}<0.01,{ }^{* * *} \mathrm{p}<0.001$

\section{Appendix D}

Wooldridge developed a very flexible test based on minimal assumptions, which can be run in STATA. The null hypothesis of this test is that there is no autocorrelation.

Table 5. Wooldridge test for autocorrelation in panel data

Wooldridge test for autocorrelation in panel data

$\mathrm{H}_{0}$ : no first-order autocorrelation

$F(1,9)=67.335$

Prob $>\mathrm{F}=0.0000$ 
The test tells us if there is a problem of autocorrelation that must be corrected (Prob> F $=0.0000)$. One way is through a fixed effects model with a Grade 1 autoregressive term (AR1) that controls the dependence of $t$ with respect to $t-1$.

\section{Appendix E}

With respect to heteroscedasticity we use the Wald test for groupwise heteroskedasticity, which works better than the Larange and Pagan multiplier test because it is sensitive to the assumption of normality of errors (GREENE, 2000, p. 598). The null hypothesis of this test is that there is no problem of heteroscedasticity. Naturally, when Ho is rejected there is a heteroscedasticity problem to be solved (Prob $>$ chi $2=0.0000)$.

Table 6. Modified Wald test for groupwise heteroskedasticity in fixed effect regression model Modified Wald test for groupwise heteroskedasticity in fixed effect regression model $\mathrm{H}_{0}: \sigma(\mathrm{i})^{2}=\sigma^{2}$ for all $\mathrm{i}$ $\operatorname{chi}^{2}(10)=60.31$ Prob $>$ chi $^{2}=0.000$

\section{Appendix F}

One of the first concerns when looking at the author's model is that it seems not to have been non-stationarity controlled. Admittedly, until recently only a few econometric works in the field of International Relations controlled for such problems.

By analyzing two non-stationary variables (Yit being explained by Xit) there is a risk of obtaining spurious regressions. Many time series variables are biased for not controlling for unit roots and could lead us to spurious liner relationships, which violate the basic assumptions of Ordinary Least Squares (OLS).

We test the existence of unit roots by using the Dickey-Fuller model (DF). The null hypothesis (Ho) calculated in STATA tests if the variable in question has a unit root. The alternative hypothesis is that the variable is stationary.

By creating a linear graph for the convergence of votes in the UNGA between the U.S. and Brazil we can observe a non-stationary behavior. The DF test has a $\mathrm{p}$ value of 0.78 indicating that it is possible to reject Ho, so that the dependent variable in Amorim Neto (2011) suffers from non-stationarity. 
Graphic 5. Non-stationary pattern of AN's dependent variable

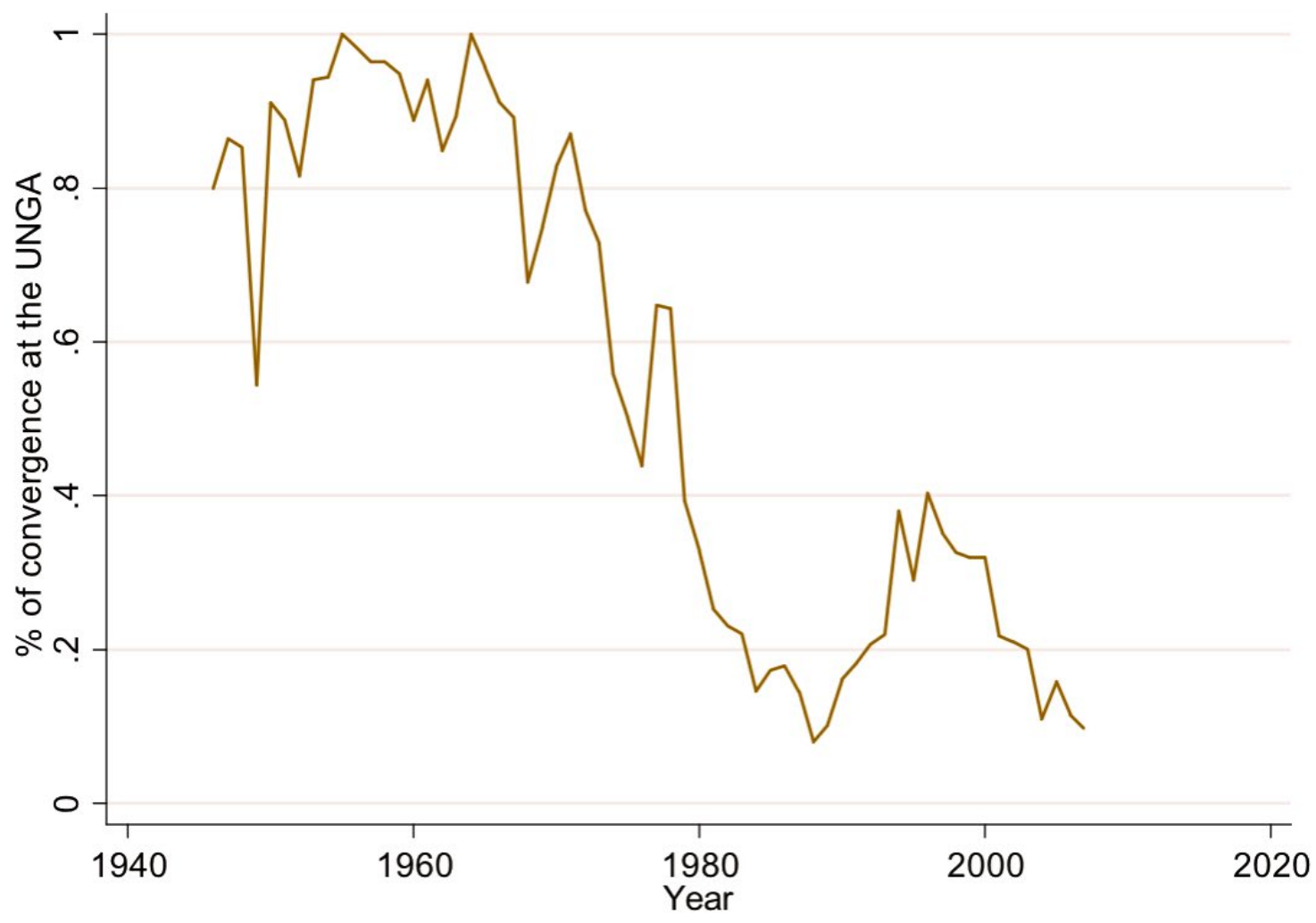

Table 6. Dickey-Fuller test for unit root

\begin{tabular}{|c|c|c|c|c|}
\hline \multicolumn{2}{|c|}{ Dickey-Fuller test for unit root } & \multicolumn{3}{|c|}{ Number of observations $=61$} \\
\hline & Test Statistic & 1\% Critical Value & 5\% Critical Value & $10 \%$ Critical Value \\
\hline $\mathrm{Z}(\mathrm{t})$ & -0.921 & -3.565 & -2.921 & -2.596 \\
\hline
\end{tabular}

MacKinnon approximate $\mathrm{p}$-value for $\mathrm{Z}(\mathrm{t})=0.7811$

The same situation occurs for his most significant explanatory variable, Brazil's CINC coefficient. A p value of 0.71 confirms that it is non-stationary. As the dependent variable is non-stationary, and the independent variable is also non-stationary, this constitutes a spurious regression, and the results must be controlled in an improved model. Otherwise it would be like using i.e. Cumulative rainfalls in Brazil as an explanatory variable and finding a great correlation with the dependent variable leading us to wrong conclusions. 
Graphic 6. Non-stationary pattern of AN's main independent variable

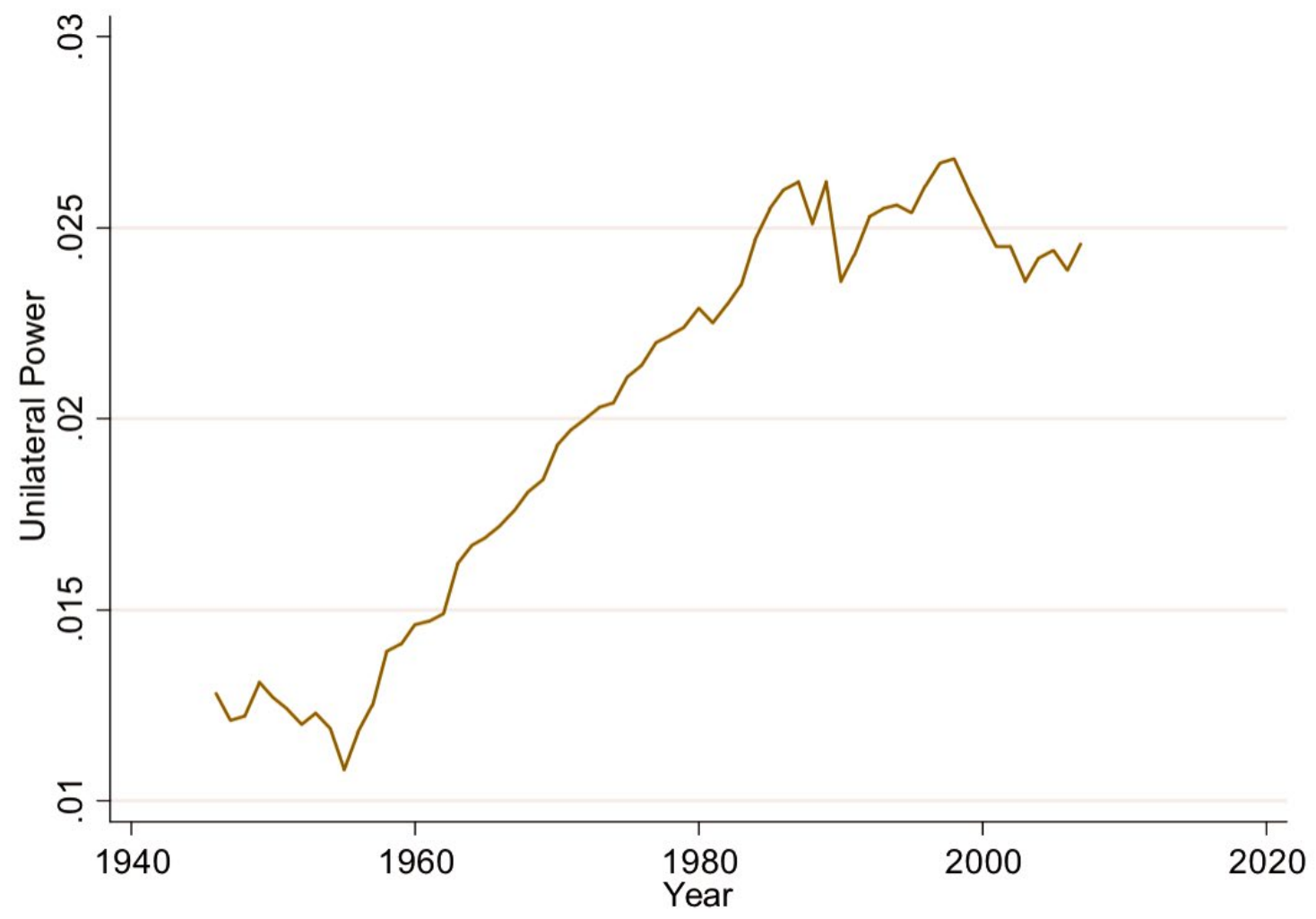

Table 7. Dickey-Fuller test for unit root

\begin{tabular}{|c|c|c|c|c|}
\hline \multicolumn{2}{|c|}{ Dickey-Fuller test for unit root } & \multicolumn{3}{|c|}{ Number of observations $=61$} \\
\hline & Test Statistic & 1\% Critical Value & 5\% Critical Value & $10 \%$ Critical Value \\
\hline $\mathrm{Z}(\mathrm{t})$ & -1.105 & -3.565 & -2.921 & -2.596 \\
\hline
\end{tabular}

MacKinnon approximate $\mathrm{p}$-value for $\mathrm{Z}(\mathrm{t})=0.7130$

The Dickey-Fuller test has been improved by several econometricians, and adapted for panel models. We used Levin and Lin Models for Table 2 Models. 